\title{
Analisis Strategi Penghidupan Petani Kopi Desa Medowo Menggunakan Pendekatan Sustainable Livelihood
}

\author{
Dwi Fauzia Putra ${ }^{1 *}$, Agung Suprianto ${ }^{1}$ \\ ${ }^{1}$ Program Studi Pendidikan Geografi, Universitas Kanjuruhan Malang, Malang 65148, Indonesia \\ Email : *dwifauziaputra@unikama.ac.id, agung.supriantogeo@gmail.com
}

Dikirim : 28 Agustus 2020

Diterima: 25 September 2020

\begin{abstract}
Abstrak: Tujuan penelitian untuk mengetahui strategi penghidupan dan karakteristik lima aset sustainable livelihood petani kopi di Desa Medowo Kecamatan Kandangan Kabupaten Kediri. Penelitian ini menggunakan metode deskriptif kuantitatif. Populasi dalam penelitian ini adalah petani kopi Desa Medowo dengan jumlah 234. Jumlah responden petani yang menjadi sampel adalah 35 petani (15\% populasi). Analisis data menggunakan statistik deskriptif dengan tabel tunggal. Hasil penelitian menunjukkan bahwa strategi penghidupan petani kopi meliputi tiga strategi: berbasis pertanian, ternak dan pertanian atau strategi campuran, aktivitas komersial dalam hal ini bisnis. Strategi penghidupan yang diterapkan petani tentunya diikuti dengan pendapatan yang diperoleh. Sebagian besar petani (51\%) berpenghasilan rendah, sedang (37\%), dan sebagian kecil (11\%) berpenghasilan tinggi. Nilai tingkat modal penghidupan petani kopi Desa medowo tergolong pada tingat keberlanjutan rendah, sedang, dan tidak berkelanjutan. Modal manusia, modal finansial, dan modal fisik merupakan modal dengan tingkat keberlanjutan rendah. Modal alam dengan tingat keberlanjutan sedang. Modal sosial menunjukkan menunjukkan tidak berkelanjutan. Oleh sebab itu perlu upaya meningkatkan kualitas modal penghidupan petani kopi minimal pada tingkat keberlanjutan sedang dan maksimal pada tingkat keberlanjutan tinggi. Studi lanjutan dapat mengkaji dimensi penghidupan keberlanjutan lainnya seperti aspek kerentanan dan kebijakan yang mempengaruhi strategi penghidupan petani kopi Desa Medowo.
\end{abstract}

Kata kunci: Strategi penghidupan, Petani, kopi, sustainable, livelihood

\begin{abstract}
The purpose of this research is to find out the livelihood strategies and characteristics of five sustainable livelihood assets and livelihood strategies of coffee farmers in Medowo Village, Kandangan District, Kediri Regency. This research uses quantitative descriptive methods. The population in this study were coffee farmers in Medowo village with 234 farmers. The number of respondent farmers sampled was 35 farmers (15\% of the population). Data analysis uses descriptive statistics with a single table. The results show that the livelihood strategies of coffee farmers include three strategies: agriculture-based, livestock and agriculture or mixed strategies, commercial activities in this case business. The livelihood strategy adopted by farmers is of course followed by the income earned. Most farmers $(51 \%)$ have low, medium income $(37 \%)$, and a small portion $(11 \%)$ have high income. The value of the capital level of livelihood of a coffee farmer in Medowo Village is classified as low, medium, and unsustainable. Human capital, financial capital and physical capital are capital with a low level of sustainability. Natural capital with a moderate level of sustainability. Social capital shows not sustainable. Therefore it is necessary to improve the quality of livelihood capital of coffee farmers at a minimum at a moderate level of sustainability and a maximum at a high level of sustainability. Further studies can examine other dimensions of sustainable livelihoods such as vulnerability and policy aspects that affect the livelihood strategies of Medowo Village coffee farmers.
\end{abstract}

Keywords: Livelihood strategies, Farmers, coffee, sustainable, livelihood

\section{Pendahuluan}

Secara administrasi, Desa Medowo terletak di Kecamatan Kandangan Kabupaten Kediri. Desa Medowo berada di ujung paling timur Kabupaten Kediri, tepatnya di lereng kaki Gunung 
Anjasmoro sehingga menjadikan daerah yang subur untuk lahan pertanian. Karena letak daerah yang subur, penduduk Desa Medowo sebagian besar bermatapencaharian sebagai petani. Penduduk bermatapencaharian petani sebesar $92.64 \%$ sedangkan mata pencaharian terbesar kedua adalah pedagang yaitu sebesar 6.7 \% (BPS, 2015). Hal ini menunjukan Desa Medowo merupakan desa yang potensial dengan potensi pertaniannya.

Kopi termasuk komoditas ekspor yang besar bagi Indonesia (Direktorat Jendral Perkebunan, 2016). Bahkan tren pertumbuhan dunia usaha kopi di Indonesia, mengalami peningkatan setiap tahunnya di atas trend dunia (Top Career, 2016). Selain itu, pengolahan kopi untuk menjadi produk setengah jadi atau jadi tidak harus membutuhkan teknologi yang modern sehingga masyarakat bisa melakukannya sendiri. Petani kopi di Desa Medowo selama ini masih belum ada yang mewadahi atau mengakomodasi baik dalam bentuk koperasi atau kelompok tani (khusus kopi). Selain itu, petani kopi untuk proses yang benar pascapanen juga belum paham. Padahal jika hal tersebut dilakukan dengan benar, akan menaikan harga jual kopi. Di mana pada akhirnya dapat meningkat pendapatan petani kopi.

Dewasa ini, Kementerian Pertanian di Indonesia sudah melakukan pertanian berkelanjutan. Meskipun wacana ini sudah diterapakan di tahun 2000-an di negara lain. Perkebunan kopi juga kedepannya diharapakan menuju produksi kopi berkelanjutan yang bertujuan untuk menerapan teknik budidaya kopi yang baik yang memperhatikan keamanan pangan, lingkungan, kesehatan, dan mutu (Kementerian Pertanian, 2014). Selain konsepsi pertanian berkelanjutan (sustainable agriculture), pengelolaan perkebunan kopi seharusnya juga memperhatikan penghidupan berkelanjutan (sustainable livelihood). Pendekatan penghidupan berkelanjutan (sustainable livelihood) sebenarnya sudah dikenal dengan baik karena manusia/petani secara inheren mengembangkan dan menerapkan strategi untuk memastikan kelangsungan hidupnya (IRP, 2015).

Pendekatan penghidupan berkelanjutan (SL) merupakan kerangka kerja alat analisis yang berguna untuk memahami banyak faktor yang mempengaruhi penghidupan seseorang dan bagaimana faktor-faktor tersebut berinteraksi satu sama lain. Kerangka kerja ini lebih memahami bagaimana orang/petani mengembangkan dan mempertahankan mata pencahariannya. Selain itu, bisa digunakan untuk merencanakan kegiatan pembangunan baru maupun untuk menilai sumbangan kegiatan-kegiatan yang sudah dilaksanakan bagi keberlanjutan penghidupan (Saragih, 2007).

Pendekatan SL melihat masyarakat mempunyai beberapa aset dalam mata pencahariannya untuk memastikan kelangsungan hidupya. Aset tersebut terdiri dari lima yaitu: 1) aset sumber daya alam dan lingkungan; 2) sosial capital; 3) finansial capital; 4) sumber daya manusia seperti pendidikan yang mampu diakses; dan 5) sumber daya infrastruktur fisik (DFID, 1991). Aset-aset ini dapat digunakan untuk mencapai strategi dan hasil penghidupan yang ditentukan sendiri untuk mengurangi kerentanan rumah tangga/masyarakat terhadap ancaman, tren, dan musiman (Bennett, 2010). Masyarakat atau petani sering secara cermat juga melakukan diversifikasi kegiatan yang merupakan hasil transformasi dari aset-aset/sumber daya/capital atau modal untuk mencapai keberlanjutan penghidupannya (Saragih, 2007).

Beberapa penelitian yang pernah dilakukan dengan pendekatan SL, diantaranya oleh Martopo (2012) dengan tujuan mengkaji kondisi keberlanjutan lingkungan, infrastruktur, ekonomi, sosial, kelembagaan, dan tingkat penghidupan berkelanjutan masyarakat di Kawasan Dieng. Hasil penelitian menunjukan tingkat penghidupannya belum berkelanjutan. Wijayanti (2016) juga pernah melakukan penelitian dengan judul Strategi Penghidupan Berkelanjutan Masyarakat Berbasis Aset di Sub DAS Pusur, DAS Bengawan Solo. Hasil penelitian menunjukkan bahwa aset tertinggi dimiliki oleh sub DAS bagian tengah, kemudian atas, dan terakhir bawah. Petani kopi Desa Medowo selama ini belum pernah diteliti dari aspek penghidupan berkelanjutan yang merupakan aspek penting bagi kesejahteraan petani. Tujuan 
penelitian ini untuk mengetahui strategi petani kopi dalam penghidupan keberlanjutan serta tingkat keberlanjutan modal penghidupan petani kopi Desa Medowo.

\section{Metode Penelitian}

Penelitian ini menggunakan metode kuantitatif dalam mengumpulkan dan menganalisis data. Penelitian ini dilaksanakan di Desa Medowo Kecamatan Kandangan Kabupaten Kediri. Secara astronomis, terletak antara $112^{\circ} 21^{\prime} 35^{\prime \prime}$ BT - $112^{\circ} 24,40^{\prime \prime}$ BT dan $7^{\circ} 43^{\prime} 48^{\prime \prime} \mathrm{LS}$ 746’50'LS. (BPS Kediri, 2016). Desa Medowo merupakan wilayah di Kabupaten Kediri paling timur. Desa Medowo berada di wilayah administrasi Kecamatan Kandangan Kabupaten Kediri. Wilayah ini mempunyai topografi dataran tinggi karena terletak di lereng Gunung Anjasmoro sehingga cocok untuk budidaya pertanian. Salah satu diantaranya adalah hasil pertanian kopi yang akan dijadikan obyek penelitian.

Luas Desa Medowo adalah 4,7 $\mathrm{km}^{2}$ yang terbagi menjadi lima dusun antara lain Dusun Sidomulyo, Dukuh Medowo, Dusun Sidorejo, Dusun Mulyorejo, dan Dusun Ringinagung. Jumlah penduduk yang ada di Desa Medowo tahun 2016 tercatat sejumlah 3345 jiwa dengan jumlah penduduk laki-laki 1674 jiwa dan penduduk perempuan 1671 jiwa. Sehingga kepadatan penduduk di Desa Medowo adalah 706 jiwa $/ \mathrm{km}^{2}$ (BPS Kediri, 2016).

\section{Pengumpulan data}

Populasi dalam penelitian ini adalah petani kopi desa medowo dengan jumlah. 234 petani (hasil survei lapangan, 2019). Penentuan sampel menggunakan asumsi bahwa kondisi yang homogen dari populasi, yaitu sama-sama petani kopi. Penentuan sampel adalah sebanyak $15 \%$ dari populasi (Leedy, 1997). Berdasarkan penentuan sampel tersebut maka jumlah responden petani yang menjadi sampel adalah 35 petani.

Teknik pengumpulan data karakteristik aset dan strategi penghidupan berkelanjutan petani kopi dilakukan melalui kuisioner dan wawancara terstruktur. Kuisioner dan wawancara terstruktur ditanyakan kepada responden masyarakat petani kopi di Desa Medowo Kecamatan Kandangan Kabupaten Kediri.

Angket disusun berdasarkan kriteria strategi penghidupan serta indikator pada lima modal penghidupan yang meliputi modal manusia, finansial, alam, fisik, dan sosial. Data sekunder sebagai pendkung berupa data kecamatan dalam angka tahun 2016 yang didapatkan dari Badan Pusat Statistik Kabupaten Kediri.

\section{Analisis data}

Analisis data dilakukan untuk menggilongkan atau mengklasifikasikan data berdasarkan kriteria strategi dan tingkat aset penghidupan berkelanjutan. Analisis data menggunakan statistik deskriptif dengan tabel tunggal. Strategi penghidupan petani kopi diperoleh dari data jenis-jenis aktifitas yang dilakukan petani dalam memenuhi kehidupannya. Pengkategorian strategi bedasarkan kategori strategi penghidupan oleh Poura, dkk (2018) yang mengkalisifikasikan strategi berdasarkan tiga aktifitas yang meliputi berbasis pada pertanian, campuran, dan komersial

Tingkat keberlanjutan modal diketahui dengan menghitung nilai penghidupan berkelanjutan pada masing-masing modal penghidupan (manusia, finansial, alam, fisik, dan sosial) Skor yang diperoleh dihitung rata-ratanya. Data yang diperolah selanjutnya dikategorikan sesuai parameter keberlanjutan sehingga diperoleh tingkat keberlanjutan baik secara total nilai ataupun pada masing-masing indikator. Setelah data dianalisis selanjutnya dilakukan 
pengkategorian data berdasarkan standar Kavanagh (2004) yaitu: skor 0-1 tidak berkelanjutan, skor $>1-2$ keberlanjutan rendah, skor $>2-<3$ keberlanjutan sedang, dan skor 3 keberlanjutan tinggi.

\section{Hasil Penelitian}

\section{Strategi pengidupan petani kopi}

Pengkategorian strategi berdasarkan kategori strategi penghidupan oleh Poura, dkk (2018) yang mengkalisifikasikan strategi berdasarkan tiga aktifitas yang meliputi berbasis pada pertanian, campuran, dan komersial. Berdasarkan hasil analisis data diperoleh strategi penghidupan petani kopi sebagau berikut.

Tabel 1. Strategi Penghidupan Petani Kopi

\begin{tabular}{llll}
\hline \multicolumn{2}{l}{ Strategi Penghidupan } & & \\
No & Jenis & Jumlah & Persentase \\
\hline 1 & Berbasis pertanian & 15 & $43 \%$ \\
2 & Campuran & 14 & $40 \%$ \\
3 & Komersial & 6 & $17 \%$ \\
\hline
\end{tabular}

(Sumber: Hasil Analisis Data, 2019)

Tabel di atas menunjukkan bahwa strategi penghidupan petani kopi meliputi tiga strategi dengan persentase yang berbeda-beda. Sebagian besar mereka menggantungkan hidupnya pada aktivitas pertanian (43\%). Sebagian lainnya menggantungkan hidupnya pada aktivitas ternak dan pertanian atau strategi campuran $(40 \%)$. Hanya sebagian kecil $(17 \%)$ menggantungkan pada aktivitas komersial dalam hal ini bisnis. Hal ini menunjukkan bahwa meskipun terdapat variasi strategi namun tidak dapat terlepas dari aktivitas bidang pertanian secara umum.

Strategi penghidupan yang diterapkan petani tentunya diikuti dengan pendapatan yang diperoleh. Berikut disajikan hasil analisis tingkat pendapatan petani. Tingkat pendapatan ini digolongkan menjadi rendah, sedang, dan tinggi.

Tabel 2. Tingkat Pendapatan Petani Kopi

\begin{tabular}{lllll}
\multicolumn{2}{l}{ Tingkat Pendapatan } & & \\
No & Tingkat & Jumlah & Persentase & Kategori \\
\hline 1 & $300000-1000000$ & 18 & $52 \%$ & Rendah \\
2 & $>1000000-1700000$ & 13 & $37 \%$ & Sedang \\
3 & $>1700000-2500000$ & 4 & $11 \%$ & Tinggi \\
\hline
\end{tabular}

(Sumber: Hasil Analisis Data, 2019)

Tabel di atas menunjukkan bahwa tingkat pendapatan petani kopi meliputi rendah, sedang, dan tinggi dengan persentase yang berbeda-beda. Sebagian besar atau labih dari separuh petani (51\%) berpenghasilan rendah. Sebagian lainnya berpenghasilan sedang (37\%). Hanya sebagian kecil $(11 \%)$ yang berpenghasilan tinggi. Hal ini menunjukkan bahwa meskiput petani telah melakukan variasi strategi penghidupan namun sebagian besar tingkat pendapatan masih pada tataran rendah.

\section{Tingkat keberlanjutan modal penghidupan petani kopi}

Tingkat keberlanjutan modal diketahui dengan menghitung nilai penghidupan berkelanjutan pada masing-masing modal penghidupan (manusia, finansial, alam, fisik, dan sosial) Skor yang diperoleh dihitung rata-ratanya. Data yang diperolah selanjutnya dikategorikan sesuai 
parameter keberlanjutan sehingga diperoleh tingkat keberlanjutan baik secara total nilai ataupun pada masing-masing indikator. Setelah data dianalisis selanjutnya dilakukan pengkategorian data berdasarkan standar Kavanagh (2004) yaitu: skor 0-1 tidak berkelanjutan, skor $>1-2$ keberlanjutan rendah, skor $>2-<3$ keberlanjutan sedang, dan skor 3 keberlanjutan tinggi.

Berikut disajikan hasil analisis data terhadap lima modal penghidupan petani. Lima modal penghidupan petani dapat dilihat pada pentagon aset di bawah ini.

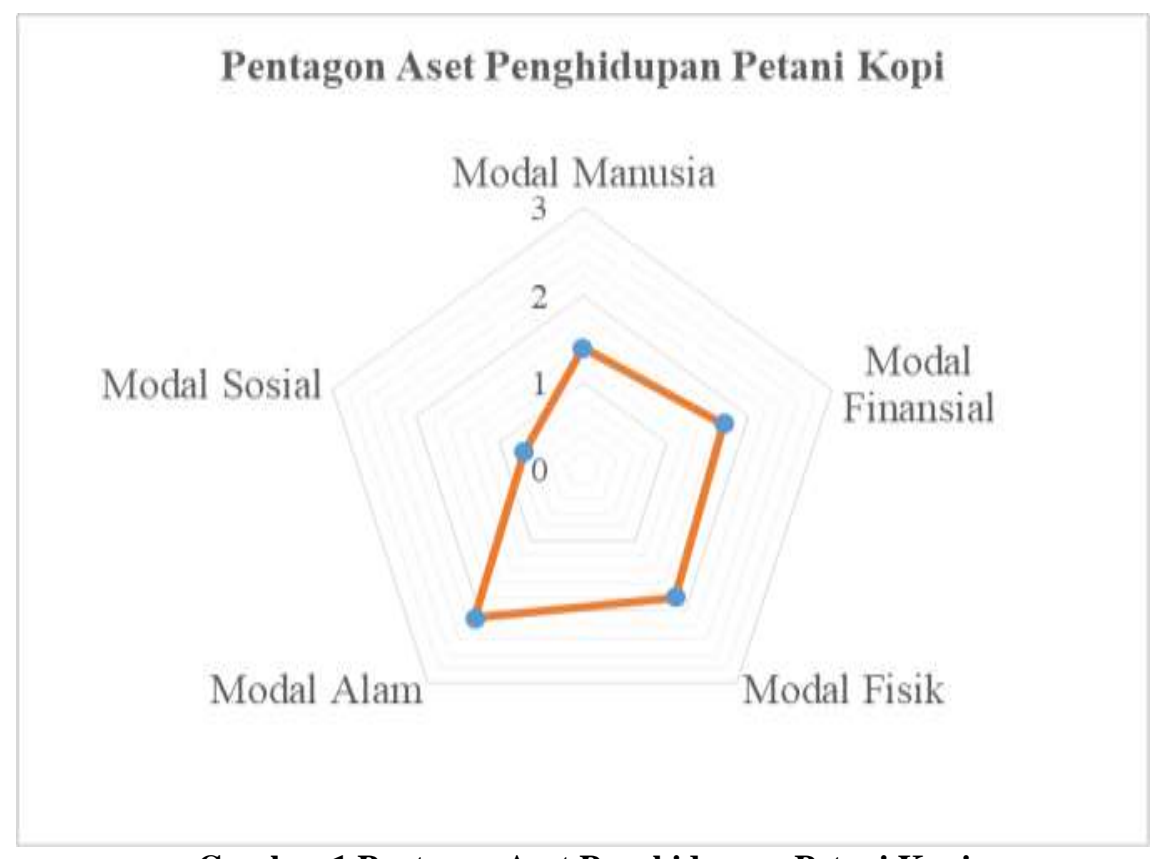

Gambar 1 Pentagon Aset Penghidupam Petani Kopi

Gambar di atas menunjukkan bahwa lima modal penghidupan petani tidak membentuk pentagon sempurna. Hal ini dikarenakan perbedaan nilai pada masing masing aset. Dari gambar tersebut dapat dilihat bahwa aset penghisupan petani berada di bawa nilai tertinggi untuk masing-masing modal penghidupan. Untuk lebih jelasnya perbedaan nilai aset dapat dilihat pada tabel berikut.

Tabel 3. Tingkat Keberlanjutan Modal Mata Pencaharian petani Kopi

\begin{tabular}{lllll}
\hline \multicolumn{2}{l}{ Modal } & & & \\
No & Dimensi & Skor Total & Rata-rata & Tingkat Keberlanjutan \\
\hline 1 & Modal Manusia & 91 & 1,4 & Rendah \\
2 & Modal Finansial & 61 & 1,7 & Rendah \\
3 & Modal Fisik & 196 & 1,8 & Rendah \\
4 & Modal Alam & 144 & 2,1 & Sedang \\
5 & Modal Sosial & 56 & 0,7 & Tidak berkelanjutan \\
\hline
\end{tabular}

(Sumber: Hasil Analisis Data, 2019)

Tabel di atas menunjukkan bahwa nilai modal penghidupan tergolong pada tingat keberlanjutan rendah, sdang, dan tidak berkelanjutan. Modal manusia, modal finansial, dan modal fisik merupakan modal dengan tingkat keberlanjutan rendah. Modal alam menjadi satusatunya modal dengan tingat keberlanjutan sedang. Modal sosial menunjukkan menunjukkan tidak berkelanjutan. Uraian lengkap ntuk masing-masing modal adalah sebagai berikut. 


\section{Modal manusia}

Modal manusia dalam penelitian ini meliputi tingkat pendidikan formal dan keahlian yang diperoleh dari pelatihan-pelatihan. Modal manusia ini berhubungan dengan pengetahuan dan kemampuan seseorang memahami informasi baru terhadap bidang yang sedang ditekuni. Hasil analisis tingkat keberlanjutan modal manusia pada petani kopi dapat dilihat pada tabel berikut:

\section{Tabel 3. Modal Manusia}

\begin{tabular}{|c|c|c|c|c|}
\hline \multicolumn{5}{|c|}{ Modal Manusia } \\
\hline No & Indikator & Skor Total & Rata-rata & Tingkat Keberlanjutan \\
\hline 1 & Pendidikan & 64 & 1,8 & Rendah \\
\hline 2 & Pelatihan & 34 & 0,9 & Tidak berkelanjutan \\
\hline \multicolumn{2}{|c|}{ Skor Total } & 98 & 1,4 & Rendah \\
\hline
\end{tabular}

(Sumber: Hasil Analisis Data, 2019)

Tabel diatas menunjukkan bahwa tingkat keberlanjutan modal manusia termasuk dalam kategori rendah dengan rata-rata skor 1,4. Rendahnya tingkat keberlanjutan modal manusia merupakan hasil dari rendahnya tingkat indikator modal manusia yang meliputi pendidikan dan pelatihan. Rata-rata pendidikan petani adalah rendah dengan rata-rata skor 1,8 atau pada tingkat sekolah dasar. Angka yang lebih rendah adalah pada indikator pelatihan yang pernah diikuti oleh petani dengan skor 0,9 atau tidak berkelanjutan. Ini menunjukkan bahwa rata-rata petani hampir tidak pernah mengikuti pelatihan-pelatihan.

\section{Modal finansial}

Modal finansial dalam penelitian ini meliputi sumber finansial. Modal finansial ini berhubungan dengan akses terhadap sumber-sumber keuangan baik melalui tabungan, bank, aau kerabat. Hasil analisis tingkat keberlanjutan modal finansial pada petani kopi dapat dilihat pada tabel berikut:

Tabel 4. Modal Finansial

\begin{tabular}{lllll}
\hline \multicolumn{2}{l}{ Modal Finansial } & & & \\
No & Indikator & Skor Total & Rata-rata & Tingkat Keberlanjutan \\
\hline 1 & Sumber Finansial & 61 & 1,7 & Rendah \\
Skor Total & 61 & 1,7 & Rendah \\
\hline
\end{tabular}

(Sumber: Hasil Analisis Data, 2019)

Tabel diatas menunjukkan bahwa tingkat keberlanjutan modal finansial termasuk dalam kategori rendah dengan rata-rata skor 1,7. Rendahnya tingkat keberlanjutan modal finansial menunjukkan bahwa akses terhadap sumber keuangan hanya terbataspada satu sumber saja diantara tiga sumber keuangan. Ini menunjukkan bahwa secara finansial untuk memenuhi kehidupannya atau yang berhubungan dengan pengelolaan pertanian petani megalami keterbatasan.

\section{Modal fisik}

Modal fisik dalam penelitian ini meliputi kepemilikan ternak, aset fisik, dan aset budidaya kopi. Modal fisik ini berhubungan dengan kepemilikan aset yang dapat dijual ketika terjadi kebutuhan mendadak, seain itu juga berupa infrastruktur penunjang budidaya kopi. Hasil analisis tingkat keberlanjutan modal fisik pada petani kopi dapat dilihat pada tabel berikut: 
Tabel 5. Modal Fisik

\begin{tabular}{lllll}
\hline \multicolumn{2}{l}{ Modal Fisik } & & & \\
No & Indikator & Skor Total & Rata-rata & Tingkat Keberlanjutan \\
\hline 1 & Ternak & 30 & 0,8 & Tidak berkelanjuan \\
2 & Aset fisik & 97 & 2,7 & Sedang \\
3 & Aset budidaya & 69 & 1,9 & Rendah \\
Skor Total & 196 & 1,8 & Rendah \\
\hline
\end{tabular}

(Sumber: Hasil Analisis Data, 2019)

Tabel diatas menunjukkan bahwa tingkat keberlanjutan modal fisik termasuk dalam kategori rendah dengan rata-rata skor 1,8. Rendahnya tingkat keberlanjutan modal fisik merupakan hasil dari tingkat indikator modal fisik. Rata-rata kepemilikan ternak petani adalah tidak berkelanjutan dengan rata-rata skor 0,8 . Indikator aset fisik petani dengan skor 2,7 dengan tingkat sedang. Aset budidaya menunjukkan angka 1,9 dengan status rendah. Ini menunjukkan bahwa meskipun aset fisik secara umum menunjukkan angkan sedang, namun untuk mendukung keberlanjutan bagi petani masih belum cukup dikarenakan aset fisik lainnya masih tergolong rendah dan tidak berkelanjutan.

\section{Modal alam}

Modal alam dalam penelitian ini meliputi luas lahan dan jarak lahan dengan tempat tinggal. Hasil analisis tingkat keberlanjutan modal alam pada petani kopi dapat dilihat pada tabel berikut:

Tabel 6. Modal Alam

\begin{tabular}{lllll}
\hline \multicolumn{2}{l}{ Modal Alam } & & & \\
No & Indikator & Skor Total & Rata-rata & Tingkat Keberlanjutan \\
\hline 1 & Luas lahan & 74 & 2,1 & Sedang \\
2 & Jarak & 70 & 2,0 & Sedang \\
Skor Total & 144 & 2,0 & Sedang \\
\hline
\end{tabular}

(Sumber: Hasil Analisis Data, 2019)

Tabel diatas menunjukkan bahwa tingkat keberlanjutan modal alam termasuk dalam kategori sedang dengan rata-rata skor 2,0. Modal alam menjadi satu-satunya ast penghidupan pada dengan tingat keberlanjutan sedang. Rata-rata luas lahan menunjukkan tingat rendah dengan rata-rata skor 2,1. Untuk jarak dengan tempat tinggal relatif dekan dengan dkor 2,0 menunjukkan tingkat keberlanjutan sedang. Ini menunjukkan bahwa petani tidak memiliki kendala dalam hal kepemilikan lahan dalam memenuhi kehdupannya.

\section{Modal sosial}

Modal sosial dalam penelitian ini meliputi tingkat partisipasi dan lamanya dalam suatu kelompok sosial. Hasil analisis tingkat keberlanjutan modal sosial pada petani kopi dapat dilihat pada tabel berikut:

Tabel 7. Modal sosial

\begin{tabular}{|c|c|c|c|c|c|}
\hline \multicolumn{6}{|c|}{ Modal Sosial } \\
\hline No & Indikator & & Skor Total & Rata-rata & Tingkat Keberlanjutan \\
\hline 1 & $\begin{array}{l}\text { Keaktifan } \\
\text { kelompok sosial }\end{array}$ & pada & 25 & 0,7 & Tidak berkelanjutan \\
\hline 2 & Lama & & 31 & 0,8 & Tidak berkelanjutan \\
\hline \multicolumn{3}{|c|}{ Skor Total } & 56 & 0,8 & Tidak berkelanjutan \\
\hline
\end{tabular}

(Sumber: Hasil Analisis Data, 2019) 
Tabel diatas menunjukkan bahwa tingkat keberlanjutan modal sosial termasuk dalam kategori tidak berkelanjutan dengan rata-rata skor 0,8 . Rata-rata petani hanya tergabung dalam satu kelompok tani dan tidak terlibat aktif sejak mereka bergabung. Ini ditunjukkan dengan rata-rata skor 0,7 atau pada tingkat tidak berkelanjutan. Lama waktu tergabung dengan kelompok tani menunjukkan skor 0,8 atau tidak berkelanjutan. Ini menunjukkan bahwa petani dalam upaya aktivitasnya untuk memenuhi kebutuhannya belum memanfaatkan modal sosial yang ada.

\section{Pembahasan}

\section{Strategi penghidupan petani kopi}

Hasil analisis data menunjukkan bahwa strategi penghidupan petani kopi meliputi tiga strategi. Hasil juga menunjukkan bahwa meskipun terdapat variasi strategi namun tidak dapat terlepas dari aktivitas bidang pertanian secara umum. Sebagian besar mereka menggantungkan hidupnya pada aktivitas pertanian (43\%). Sebagian lainnya menggantungkan hidupnya pada aktivitas ternak dan pertanian atau strategi campuran (40\%). Hanya sebagian kecil (17\%) menggantungkan pada aktivitas komersial dalam hal ini bisnis.

Strategi penghidupan yang diterapkan petani tentunya diikuti dengan pendapatan yang diperoleh. Sebagian besar atau labih dari separuh petani (51\%) berpenghasilan rendah. Sebagian lainnya berpenghasilan sedang (37\%). Hanya sebagian kecil (11\%) yang berpenghasilan tinggi. Hal ini menunjukkan bahwa meskipun petani telah melakukan variasi strategi penghidupan namun sebagian besar tingkat pendapatan masih pada tataran rendah. Hal ini sejalan dengan temuan Martopo, Hardiman, dan Suharyanto (2012) bahwa strategi penghidupan berdampak pada pendapatan petani. Kondisi petani kopi menunjukkan rata-rata strategi penghidupan berkisar pada petanian dengan rata-rata pendapatan yang rendah. Kondisi ini tidak lepas dari karakteristik modal yang dimiliki. Seperti halnya karakteristik penghidupan masyarakat di desa-desa di Dieng menunjukkan kondisi yang tidak berkelanjutan dipengaruhi oleh ketidakberlanjutan aset-aset yang dimiliki.

Hal tersebut menandakan bahwa karakteristik modal penghidupan memberikan dampak terhadap pendapatan yang rata-rata strategi penghidupannya sebagai petani. Hasil penelitian oleh Rosyida dan Rudiarto (2014) menunjukkan kurangnya modal terutama finansial dan sosial berdampak pada rendahnya penghasilan petani. Dengan demikian upaya perbaikan terhadap peningkatan aset akan memberikan dampak terhadap strategi dan peningkatan terhadap pendapatan petani kopi Desa Medowo. Peningkatan terhadap aset penghidupan dapat meningkatkan penghidupan petani kopi dimana kondisi tingkat penghidupan yang layak dapat mengatasi berbagai guncangan dan tekanan (Febriharjati dan Setyono, 2015).

\section{Tingkat keberlanjutan modal penghidupan petani kopi}

Strategi penghidupan yang dipilih oleh rumah tangga dalam hal ini petani kopi dipengaruhi oleh penguasaan aset yang dimiliki (Scoone, 2001; DFID,2011). Penguasaan aset meliputi Modal Manusia, Modal Alam, Modal sosial, Modal Fisik dan Modal finansial. Semakin banyak penguasaan aset oleh petani kopi di Desa Medowo maka strategi penghidupan rumah tangga akan semakin bervariasi. Peningkatan terhadap aset penghidupan dapat meningkatkan penghidupan petani kopi dimana kondisi tingkat penghidupan yang layak dapat mengatasi berbagai guncangan dan tekanan (Febriharjati dan Setyono, 2015).

Modal manusia yang dimiliki petani di Desa Medowo mununjukan pada tingkat tidak berkelanjutan atau rendah. Rendahnya modal manusia yang dimiliki tentunya berpengaruh 
terhadap pencapaian penghidupan berkelanjutan petani kopi yang dituju tidak tercapai. Sesuai dengan kajian teori dari DFID (2001) bahwa karakteristik modal manusia tinggi atau berkelanjutan yang dimiliki petani akan memberikan dampak terhadap pencapaian tujuan dalam hidupnya. Hal ini, dikarenakan modal manusia akan menunjukan ketrampilan/kemampuan, kesehatan, pengalaman seseorang yang bersinergi untuk melakukan strategi penghidupan yang ingin dicapai.

Selain itu, hasil penelitian juga menunjukan tidak berkelanjutannya modal manusia petani di Desa Medowo karena sebagian besar petani tidak mengikuti pelatihan dan pelatihan yang tidak berkelanjutan. Padahal untuk mencapai modal manusia yang berkelanjutan maka petani harusnya banyak mengikuti pelatihan-pelatihan yang berkelanjutan dan teroganisir. Hal ini sejalan dengan yang dijelaskan Moran dalam Saleh (2014) bahwa kemampuan meningkat seiring dengan pendidikan dan pelatihan, pengetahuan meningkat karena memiliki akses informasi dan kemampuan berkerja meningkat karena sehat, ketrampilan dan motivasi.

Modal finansial biaasanya merupakna aset ekonomi merupakan gambaran penguasaan rumah tangga akan kemudahan pemenuhan segi keuangan yang bersumber dari tabungan, upah, kredit, dan hutang ataupun barang yang bernilai ekonomis (Scoones, 2001; DFID, 2001). Akses petani dan nelayan terhadap modal finansial sangat beragam tergantung kepada jenis kebutuhan dan keterbukaan terhadap peluang untuk memanfaatkannya. Petani kopi di Desa Medowo memiliki modal finansial dalam kategori tidak berkelanjutan atau rendah. Hal dikarenakan sumber aset untuk memperoleh modal finansial jumlahnya terbatas. Rendahnya modal finasial juga akan berpengaruh terhadap strategi penghidupan berkelanjutan petani, karena modal finansial akan memberikan banyak alternatif dalam mengambil strategi kedepannya. Rendahnya modal finansial juga akan memberikan terhadap besarnya pendapatan yang diperoleh petani. Karakteristik modal penghidupan memberikan dampak terhadap pendapatan yang rata-rata strategi penghidupannya sebagai petani. Hasil penelitian oleh Rosyida dan Rudiarto (2014) menunjukkan kurangnya modal terutama finansial dan sosial berdampak pada rendahnya penghasilan petani.

Modal fisik yang dimiliki oleh petani kopi di Desa Medowo pada umumnya masih menunjukan kategori rendah atau tidak berkelanjutan. Penguasaan aset sumberdaya fisik merupakan gambaran kemudahan akses berupa sarana dan prasarana yang mendukung rumah tangga, yaitu petani kopi dalam bertahan hidup (Scoones, 2001; DFID, 2001). Modal fisik menujukan kepemilikan aset fisik seseorang dalam rumah tangga.

Petani kopi di Desa Medowo yang umumnya memiliki modal fisik rendah belum mampu mencapai penghidupan keberlanjutan yang diharapkan. Hal ini, dikarenakan aset atau modal fisik mempunyai nilai keberlanjutan yang baik atau tinggi jika petani mampu melakukan intensifikasi dan diversifikasi terhadap strategi penghidpuan mereka. Hal ini ditandai dengan banyak atau bertambahnya strategi usaha dalam aset fisik untuk mempertahankan penghidupan berkelanjutan mereka (Wijayanti, Baiquni, dan Harini, 2016).

Modal alam yang dimiliki petani di Desa Medowo dalam kategori sedang, paling tinggi di antara kelima modal lainnya. Petani kopi yang memiliki modal alam dapat dimanfaatkan untuk memperoleh akses terhadap penghidupan yang lebih baik. Modal alam berasal dari alam dan digunakan untuk memenuhi kebutuhannya (DFID, 2001). Modal alam juga dianggap sangat penting karena manusia tidak dapat hidup dari jasa-jasa lingkungan dan makanan yang berasal dari alam (Carney, 1998).

Modal alam yang dimiliki petani kopi di Desa Medowo sebeanrnya sudah dapat mencapai keberlangsungan hidup mereka karena umunya pada kategori sedang. Hal ini sesuai dengan hasil penelitian Saleh (2014) bahwa modal alam yang dimiliki petani berbanding lurus dengan strategi penghidupan mereka. Artinya, semakin tinggi tingkat keberlajutan yang modal alam maka strategi penghidupan petani akan semakin tinggi dari sekedar hanya untuk bertahan hidup 
saja. Namun, hal tersebut belum bisa tercapai karena kepemilikan aset atau modal yang lainnya dalam kategori rendah atau belum berkelanjutan.

Kepemilikan aset atau modal sosial petani kopi di Desa Medowo masih tergolong rendah atau tidak berkelanjutan. Modal sosial merupakan gambaran kemudahan dalam jaringan sosial yang dimanfaatkan rumah tangga baik formal maupun informal yang menjadi tumpuan untuk dapat bertahan hidup (Scoone, 2001; DFID, 2001). Modal sosial menunjukkkan bagaimana rumah tangga memiliki interaksi dengan masyarakat lain dilingkungan sosialnya. Modal sosial dianggap mampu meningkatkan kepercayaan (mutual trust) dan mengurangi biaya bekerja secara bersama-sama (DFID, 2001).

Modal sosial petani kopi di Desa Medowo tergolong rendah karena keikutsertaan mereka dalam organisasi/keloompok tani masih sebentar dan bahkan banyak yang tidak tergabung. Sehingga rendahnya modal sosial juga berpengaruh terhadap strategi yang mereka ambil dan pendapatan yang rendah. Hal ini sejalan dengan penelitian oleh Rosyida dan Rudiarto (2014), yang menunjukkan kurangnya modal terutama finansial dan sosial berdampak pada rendahnya penghasilan petani. Peningkatan indikator modal sosial yang dimiliki petani kopi dalam mewujudkan penghidupan berkelanjutan dapat melalui beberapa cara. Misalnya, seperti hasil penelitian oleh (Triyanti dan Firdaus, 2016) dengan peningkatan akses masyarakat terhadap kelembagaan ekonomi, mengoptimalkan kelembagaan masyarakat yang ada khususnya dalam setiap program pemerintah, mengintegrasikan kelembagaan informal dengan kelembagaan formal, dan mengaktifkan kembali koperasi yang telah ada atau mendirikan koperasi perikanan baru.

\section{Kesimpulan}

Berdasarkan hasil penelitian dan pembahasan dapat ditarik kesimpulan bahwa strategi penghidupan petani kopi meliputi tiga strategi. Sebagian besar mereka menggantungkan hidupnya pada aktivitas pertanian (43\%). Sebagian lainnya menggantungkan hidupnya pada aktivitas ternak dan pertanian atau strategi campuran (40\%). Hanya sebagian kecil (17\%) menggantungkan pada aktivitas komersial dalam hal ini bisnis. Strategi penghidupan yang diterapkan petani tentunya diikuti dengan pendapatan yang diperoleh. Sebagian besar atau labih dari separuh petani $(51 \%)$ berpenghasilan rendah. Sebagian lainnya berpenghasilan sedang (37\%). Hanya sebagian kecil (11\%) yang berpenghasilan tinggi. Nilai tingkat modal penghidupan petani kopi Desa medowo tergolong pada tingat keberlanjutan rendah, sedang, dan tidak berkelanjutan. Modal manusia, modal finansial, dan modal fisik merupakan modal dengan tingkat keberlanjutan rendah. Modal alam menjadi satu-satunya modal dengan tingat keberlanjutan sedang. Modal sosial menunjukkan menunjukkan tidak berkelanjutan. Merujuk pada kesimpulan di atas, maka saran yang diberikan bagi pemerintah daerah hendaknya membantu masyarakat dalam upaya meningkatkan kualitas modal penghidupan petani kopi Desa Medowo minimal pada tingkat keberlanjutan sedang dan maksimal pada tingkat keberlanjutan tinggi. Sedangkan, saran yang dapat dilakukan oleh peneliti selanjutnya hendaknya mengkaji dimensi penghidupan keberlanjutan lainnya seperti aspek kerentanan dan kebijakan yang mempengaruhi strategi penghidupan petani kopi Desa Medowo.

\section{Ucapan Terimakasih}

Ucapan terimakasih kami sampaikan kepada Universitas Kanjurahan Malang, masyarakat Desa Medowo yang telah bersedia memberikan waktu luang serta informasi selama proses pengumpulan data. 


\section{Daftar Rujukan}

Bennett, Nathan. 2010. Sustainable Livelihoods from Theory to Conservation Practice: An Extended Annotated Bibliography for Prospective Application of Livelihoods Approaches in Protected Area Community Research. Victoria, Canada: Protected Area and Poverty Reduction Alliance Working Paper No. 1.

BPS Kabupaten Kediri. 2015. Kabupaten Kediri Dalam Angka. Kediri: Badan Pusat Statistik Kabupaten Kediri.

Carney, D. 1998. Implementing the Sustainable Rural Livelihoods Approach. In Carney (ed.) Sustainable Rural Livelihoods. What Contributions can we make? Department for International Development Nottingham: Russell Press Limited.

DFID. (1999). Sustainable Livelihoods Guidance Sheets. London: Department for International Development.

DFID. 2001. Sustainable livelihoods Guidance Sheets. Department for International Development,http://www.livelihoods.org/

Direktorat Jendral Perkebunan. 2016. Statistik Perkebunan Indonesia "2105-2107 Kopi". Jakarta: Sekertaris Direktorat Jendral Perkebunan.

Febriharjati dan Setyono. 2015. Keberlanjutan Penghidupan Petani Kopi Desa Tlahab, Kecamatan Kledung, Kabupaten Temanggung. Jurnal Teknik PWK Volume 4 Nomor 4 2015 Online: http://ejournal-s1.undip.ac.id/index.php/pwk

IRP. 2015. Guidance Note on Recovery: Livelihood. Japan: International Recovery Platform Scretariat.

Kavanagh. P. 2004. Implementing Microsoft Exel Software For Rapfish: A Technique For Rapis Aparsial of Fisheries Ststus. Fisheries Center Research Report 2004 Vol. 12. No. 2. University of british Columbia. Canada

Kementerian Pertanian. 2014. Peraturan Menteri Pertanian Nomor 49/Permentan/OT.140/4/2014 “Pedoman Teknis Budidaya Kopi yang Baik”. Jakarta: Direktorat Jendral Perkebunan.

Leedy, D. Paul. 1997. Practical Research: Planning and desighn. Amerika: Prentice-Hall, Inc Martpo, dkk. 2012. Kajian Tingkat Penghidupan Berkelanjutan (Sustainable Livelihood) Di Kawasan Dieng (Kasus Di Dua Desa Kecamatan Kejajar Kabupaten Wonosobo). Prosiding Seminar Nasional Pengelolaan Sumberdaya Alam dan Lingkungan, Semarang, 11 September 2012

Poura, Milad Dehghani. Baratia, Ali Akbar. Azadib, Hossein. and Scheffranb, Jürgen. 2018. Revealing The Role Of Livelihood Assets In Livelihood Strategies: Towards Enhancing Conservation And Livelihood Development In The Hara Biosphere Reserve, Iran. Ecological Indicators 94 (2018) 336-347. https://doi.org/10.1016/j.ecolind.2018.05.074

Rosyida dan Rudiarto. 2014. Karakteristik Sosial Ekonomi Masyarakat Petani Kecamatan Bandar Dalam Sistem Livelihood Pedesaan. Geoplanning, volume 1, No 2, 2014, 74-84, E-ISSN: 2355-6544

Saleh. 2014. Laporan Akhir Penelitian Disertasi Doktor: Strategi Penghidupan Penduduk Sekitar Danau Limboto Provinsi Gorontalo. Universitas Negeri Gorontalo.

Saleh. 2014. Strategi Penghidupan Penduduk Sekitar Danau Limboto Provinsi Gorontalo. Disertasi: Tidak dipublikasikan. Universitas Negeri Gorontalo

Saragih, dkk. 2007. Kerangka Penghidupan Berkelanjutan "Sustainable livelihood Framework".

Satge, Rick de. 2002. Learning about livelihoods Insights from Southern Africa. Periperi Publications and Oxfam Publishing. 
Scoone, 2001, Sustainable Rural Livelihoods A Framework For Analysis. IDS Working Paper 72. Institute of Development Studies.

Top career. 2016. Roaster, Barista, Hingga Mixology. Jakarta: Top Career Your Golden Compas Magazine.

Triyanti dan Firdaus. 2016. Tingkat Kesejahteraan Nelayan Skala Kecil Dengan Pendekatan Penghidupan Berkelanjutan Di Kabupaten Indramayu. J. Sosek KP Vol. 11 No. 1 Juni 2016: 29-43

Triyanti. 2016. Tingkat Kesejahteraan Nelayan Skala Kecil Dengan Pendekatan Penghidupan Berkelanjutan Di Kabupaten Indramayu. Jurnal: J. Sosek KP Vol. 11 No. 1 Juni 2016: 29-43 Pusat Penelitian Sosial Ekonomi Kelautan dan Perikanan

Wijayanti, Baiquni, dan Harini. 2016. Strategi Penghidupan Berkelanjutan Masyarakat Berbasis Aset di Sub DAS Pusur, DAS Bengawan Solo Jurnal wilayah dan Lingkungan P-ISSN: 2338-1604 dan E-ISSN: 2407-8751 Volume 4 Nomor 2, Agustus 2016, 133-152 http://dx.doi.org/10.14710/jwl.4.2.133-152 